
medRxiv preprint doi: https://doi.org/10.1101/2021.10.28.21265544; this version posted October $29,2021$. The copyright holder for this
preprint (which was not certified by peer review) is the author/funder, who has granted medRxiv a license to display the preprint in It is made available under a CC-BY 4.0 International license.

\title{
In vitro characterisation and clinical evaluation of the diagnostic accuracy of a new antigen test for SARS-CoV-2 detection.
}

\author{
Montoya, J.J. ${ }^{1}$, Rubio, J.M. ${ }^{2}$, Ouahid, Y. ${ }^{3}$, Lopez, A. ${ }^{3}$, Madejon, A. ${ }^{4}$, Gil-Garcia, A.I. ${ }^{3}$, \\ Hannam, R.J. ${ }^{5}$, Butler, H.R.E. ${ }^{5}$ and Castan, P. ${ }^{3}$ \\ 1. Departamento de Radiología, Rehabilitación y Fisioterapia. Facultad de Medicina, Universidad \\ Complutense de Madrid.
}

2. Centro Nacional de Microbiología, Instituto de Salud Carlos III, Ctra. de Pozuelo, 28, 28222 Majadahonda, Madrid

3. Unidad de Desarrollo de Herramientas Moleculares para Diagnostico e Investigación Clínica (UDHM-DC), MiRNAX Biosens (Avda. Industria $n^{\circ} 4$, Edificio 1) en colaboración con el Hospital Carlos III/ISCIII C/ Sinesio Delgado 10, 28029-MADRID, Hospital La Paz, Madrid, Spain.

4. Centro de Investigación Biomédica en Red, C/ Sinesio Delgado 10, 28029-MADRID, Hospital La Paz, Madrid, Spain.

5. Avacta Life Sciences, Unit 20, Thorp Arch Estate, Wetherby, LS23 7FA, UK.

\section{Abstract}

Background and aims: Quick, user-friendly and sensitive diagnostic tools are the key to controlling the spread of the SARS-CoV-2 pandemic in the new epidemiologic landscape. The aim of this work is to characterise a new Covid-19 antigen test that uses an innovative chromatographic Affimer ${ }^{\circledR}$-based technology designed for the qualitative detection of SARS-CoV-2 antigen. As rapid technology to detect Covid19 , the test was extensively characterised in vitro. Once the analytical parameters of performance were set, the test system was challenged in a test field study. The aim of this study was to evaluate its diagnostic accuracy, as compared by the gold standard RT-PCR and other existing lateral flow tests.

Keywords: respiratory disease COVID-19; SARS-CoV-2; ELISA; RT-PCR; antigen lateral flow test.

\section{Introduction}

In late December, 2019, a number of patients with viral pneumonia were found to be epidemiologically associated with the Huanan seafood market in Wuhan, in the Hubei province of China. A novel, human-infecting coronavirus, provisionally named 2019 Novel Coronavirus (2019-nCoV) and since renamed SARS-CoV-2, was

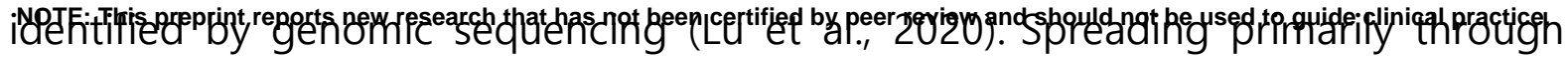


medRxiv preprint doi: https://doi.org/10.1101/2021.10.28.21265544; this version posted October $29,2021$. The copyright holder for this preprint (which was not certified by peer review) is the author/funder, who has granted medRxiv a license to display the preprint in It is made available under a CC-BY 4.0 International license.

contact with an infected person through respiratory droplets, the incubation period for this virus was confirmed to extend from 2-11 days, causing a series of clinical symptoms that range from mild evidences of runny nose, sore throat, cough, and fever to more severe cases of pneumonia and/or breathing difficulties. In this pandemic context, there has been over $170 \mathrm{M}$ cases of COVID-19 reported worldwide and 3,5 M deaths by the end of July $2021^{1.2 .3}$.

Having to endure a strong lack of molecular diagnostic equipment and testing supplies during the pandemic, molecular biologists have been developing alternatives to help medical professionals accurately diagnose cases of COVID-19, pivoting from RTqPCR from oropharyngeal and/or nasal swabs, to more immediate direct detection of viral antigens in order to generate a combination that had previously proven useful to combat outbreaks of Zika and Ebola ${ }^{4,5,6}$. In this scenario, propelled by the global pandemic, researchers in the UK, have developed a novel biotinylated anti SARS-CoV-2 S1 Affimer ${ }^{\circledR}$ technology that binds to the SARS-CoV2-S1 protein in anterior nasal swab samples, generating a complex that migrates along a lateral flow strip by capillary action implementing an innovative ultrasensitive Lateral Flow Device (LFD) based on the interaction of immobilized polystreptavidin with the migrating complex, via the available biotin label on the anti SARS-CoV-2 S1 Affimer ${ }^{\circledR 7,8}$.

This novel anti SARS-CoV-2 S1 Affimer ${ }^{\circledR}$ technology capitalizes on the scientific confirmation that the SARS-CoV-2 2-S1 protein binds to the angiotensinconverting enzyme 2 (ACE2) receptor in humans (Lu et al., 2020) mediating fusion of the viral and cellular membranes $(L i, 2016)$. The LFD tested in this work detects the SARS-CoV-2-S1 protein thorough binding to the novel Affimer ${ }^{\circledR}$ technology, thus targeting a key element in terms of function and structural accessibility, for the $S$ protein assembles to form the trimer spikes protruding from the viral envelope that bring the viral and cellular membranes close for fusion ${ }^{9,10}$. 
medRxiv preprint doi: https://doi.org/10.1101/2021.10.28.21265544; this version posted October $29,2021$. The copyright holder for this preprint (which was not certified by peer review) is the author/funder, who has granted medRxiv a license to display the preprint in It is made available under a CC-BY 4.0 International license.

\section{Objectives}

The starting point was to select the lead anti SARS-CoV-2 S1 Affimer ${ }^{\circledR}$ candidate for efficient binding to the SARS-CoV-2-S1 protein in anterior nasal swab samples and further migration of the complex, based on the characterization of the binding kinetics of the Affimer ${ }^{\circledR}$ reagents towards SARS-CoV-2 S1 protein in a label-free surface plasmon resonance imaging (SPRi) system ${ }^{11,12}$.

To complete the in vitro characterisation of the selected biotinylated anti SARSCoV-2 S1 Affimer ${ }^{\circledR}$ within the system, a complete set of tests was performed using purified viral protein. Cross-reactivity and interference tests were completed to generate a specificity profile of the LFD against a) recombinant S1 coronavirus targets and b) common nasal sprays. The analytic Limit of Detection (LoD) was defined, utilizing a) the entire test system from sample preparation to detection and b) spiking inactivated virus (e.g., irradiated virus) into real clinical matrix (e.g., nasopharyngeal (NP) swabs) ${ }^{13,14,15}$.

To complete the estimation of the clinical performance (and roughly compare to the in vitro data) a total of 250 samples from volunteers enrolled in test-field epidemiologic studies was analysed, and the sensitivity and specificity were calculated and compared to the RT-PCR data from nasopharyngeal swabs. The studies were completed under the frame of Project SENSORNAS RTC-20176501 in collaboration with MiRNAX Biosens Ltd. and Hospital Carlos III, including a total of 150 negative samples and 100 positive samples, each test documented internally and deposited in agreement to the ISO 15189 norm.

\section{Materials and Methods}

The selection of the lead biotinylated anti SARS-CoV-2 S1 Affimer ${ }^{\circledR}$ candidate(s) was performed attending to the binding kinetics towards SARS-CoV-2 S1 protein. To this end, a set of Affimer ${ }^{\circledR}$ candidates containing a single cysteine were diluted to $5 \mu \mathrm{M}$ in $10 \mathrm{mM}$ sodium phosphate, $2.7 \mathrm{mM}$ potassium chloride, $137 \mathrm{mM}$ sodium chloride, pH 7.4 (Sigma Aldrich, P4417) and were printed in triplicate to Epoxydefunctionalised SPRi-Biochips (HORIBA, CEp) using an SPRi-Arrayer (HORIBA). The resulting Biochips were incubated $\left(18{ }^{\circ} \mathrm{C}, 55 \% \mathrm{RH}\right.$ for $16 \mathrm{~h}$ ), quenched with $25 \mathrm{mM}$ 
medRxiv preprint doi: https://doi.org/10.1101/2021.10.28.21265544; this version posted October 29, 2021. The copyright holder for this preprint (which was not certified by peer review) is the author/funder, who has granted medRxiv a license to display the preprint in It is made available under a CC-BY 4.0 International license .

Ethanolamine (Sigma Aldrich, E9508), $10 \mathrm{mM}$ sodium phosphate, $2.7 \mathrm{mM}$ potassium chloride, $137 \mathrm{mM}$ sodium chloride, pH 7.4 (Sigma Aldrich, P4417), and finally rinsed 4x using 18.2 M $\Omega . c m$ ultrapure water (Milli-Q ${ }$, Merk-millipore). After assigning spot definitions to the printed Affimer ${ }^{\circledR}$ spots using EZSuite (Ver 1.4.1.68, HORIBA), the biochip was blocked with $1 \times$ Casein Blocking Buffer (Sigma Aldrich, B6429) in PBS-T, $200 \mu \mathrm{L}$ injection, $25 \mu \mathrm{L} / \mathrm{min}$ for 10 minutes. Reponses for each printed Affimer ${ }^{\circledR}$ spot were then normalised using an injection of $3 \mathrm{mg} / \mathrm{mL}$ Sucrose (Fisher Scientific, S/8600/53). Analyte injections of SARS-CoV-2 S1 protein (ACRO Biosystems, $\mathrm{S} 1 \mathrm{~N}-\mathrm{C} 52 \mathrm{H} 3$ ), were performed at concentrations ranging from $100 \mathrm{nM}$ to $3 \mathrm{nM}$. Response data for all SARS-CoV-2 S1 analyte injection concentrations was exported from EZSuite and analysed using Scrubber2 (Ver2.0g, HORIBA). Further referencing was performed against the negative reference Affimer ${ }^{\circledR}$ spots, and the association rate constant $(\mathrm{ka})$, dissociation rate constant $(\mathrm{kd})$ and equilibrium dissociation constant (KD) were then determined by fitting using a 1:1 Langmuir model.

In vitro characterisation of the novel anti SARS-CoV-2 S1 Affimer ${ }^{\circledR}$ technology: cross-reactivity and interference testing.

A specificity profile of the system was completed against recombinant S1 coronavirus targets (Table 3 ) with cross-reactivity observed for SARS-CoV only. In this system, the biotinylated anti SARS-CoV-2 S1 Affimer ${ }^{\circledR}$ reagent binds to the SARS-CoV-2-S1 protein and the antigen-Affimer ${ }^{\circledR}$ complex is then specifically bound to conjugated microparticles. The antigen-Affimer $\AA$-microparticle complex migrates along the lateral flow strip by capillary action until it reaches the test line. When contact is made, the immobilized poly-streptavidin on the test line binds the complex via the available biotin label on the Affimer ${ }^{\circledR}$ reagent, whilst the unbound microparticles continue along the lateral flow strip until they reach the control line. Interference testing was also performed with 3 common nasal sprays (Table 4).

In vitro characterisation of the novel anti SARS-CoV-2 S1 Affimer ${ }^{\circledR}$ technology: determination of the limit of detection (LoD). 
medRxiv preprint doi: https://doi.org/10.1101/2021.10.28.21265544; this version posted October $29,2021$. The copyright holder for this preprint (which was not certified by peer review) is the author/funder, who has granted medRxiv a license to display the preprint in It is made available under a CC-BY 4.0 International license.

A pool of (SARS-CoV-2 negative) anterior nasal swab samples inoculated with the inactivated virus (England 02 strain lot 19/60) was diluted to $10^{4}, 10^{3}, 5 \times 10^{2}, 10^{2}$ and $5 \times 101 \mathrm{pfu} / \mathrm{mL}$ (Figure 1). Confirmatory testing was performed at 1581, 500 and $158.1 \mathrm{pfu} / \mathrm{mL}$ giving a pass rate of 20/20 for $1581 \mathrm{pfu} / \mathrm{mL}$ and $17 / 20$ for $500 \mathrm{pfu} / \mathrm{mL}$. The final LoD was defined as the lowest concentration resulting in positive detection of 18 out of 20 replicates ( $90 \%$ of all true positives). Assessment of the LFD test was visual. Digital read outs of the line intensity (both test and control) were also generated using a Cube reader.

The estimation of the clinical performance with clinical samples from volunteers enrolled in test-field epidemiologic studies was designed so as to assess the clinical usefulness of the AffiDX® SARS-CoV-2 Antigen Rapid test based on the novel SARS-CoV-2 S1 Affimer ${ }^{\circledR}$ technology, using a nasal swab to confirm the presence of SARS-CoV-2. The studies were completed under the frame of Project SENSORNAS RTC-20176501 in collaboration with MiRNAX Biosens Ltd. and Hospital Carlos III, including a total of 250 samples (150 negatives and 100 positives), each test was documented internally and deposited in agreement to the ISO 13485 norm. comparing the LFD results with results that had been previously obtained from the RTqPCR which was set as the gold standard for detection of SARS-CoV2. The clinical performance was then estimated within this retrospective structure test-field study collating the positive specimens from consenting patients of any age, gender, or race/ethnicity who presented at the test site with a former PCR confirmation for COVID-19 no older than 4 days. Negative specimens were obtained from consenting patients of any age, gender, or race/ethnicity who presented at the test site with a former negative PCR for COVID-19 no older than 4 days. All LFD tests were performed by minimally trained operators with little laboratory experience who received no previous training on use of the AffiDX® SARS-CoV-2 Antigen Rapid test performed the study test evaluations and were, therefore, representative of the intended users. Study samples: 100 positive (with Ct values $\leq 30$ ) and 150 negative donors all recently confirmed by RTqPCR were asked to provide the anterior nasal swab which was used to assess the AffiDX® antigen LFD. 
medRxiv preprint doi: https://doi.org/10.1101/2021.10.28.21265544; this version posted October 29, 2021. The copyright holder for this preprint (which was not certified by peer review) is the author/funder, who has granted medRxiv a license to display the preprint in It is made available under a CC-BY 4.0 International license .

\begin{tabular}{|l|l|}
\hline Type of extraction & Extraction protocol - MaxwelI ${ }^{\circledR}$ RSC Buccal Swab RNA Kit \\
\hline Type of RTqPCR assay & Applied Biosystems TaqPath COVID-19 CE-IVD RT-PCR \\
\hline
\end{tabular}

Table 0. Summary of consumables used for estimation of the clinical performance from volunteers enrolled in test-field epidemiologic studies.

\section{Results}

Affimer ${ }^{\circledR}$ candidate 620_826257 generated the binding kinetics towards SARS-CoV2 S1 protein as shown in figure 1, where the SPRi sensorgrams show results in triplicate across the series of injections (100 nM to 3 nM SARS-CoV-2 S1 protein).

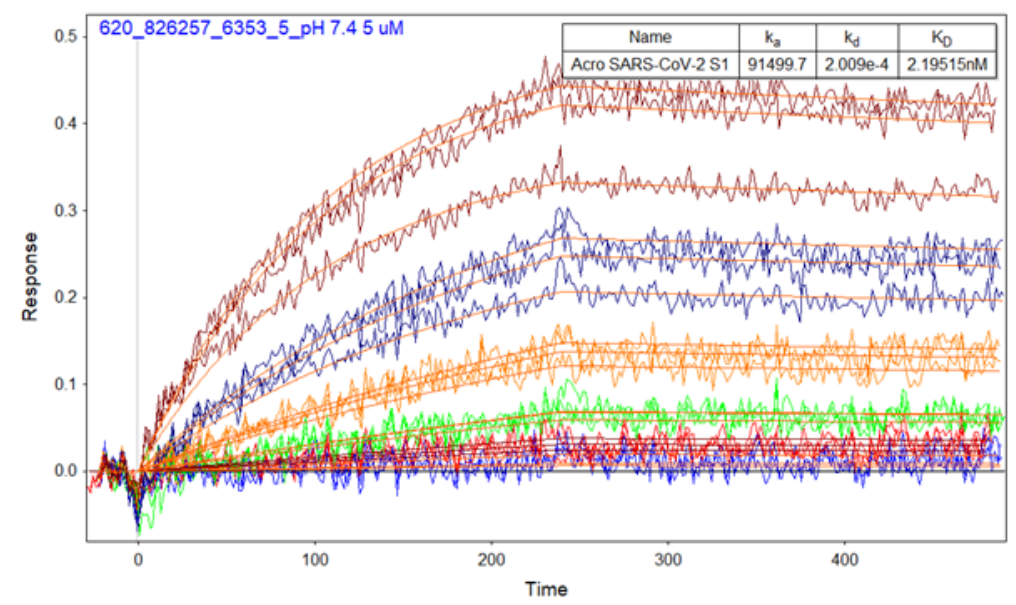

Figure 1. SPRi sensorgrams for triplicate spots of Affimer ${ }^{\circledR}$ candidate 620_826257 with injections of $100 \mathrm{nM}-3 \mathrm{nM}$ SARS-CoV-2 S1 protein, overlayed with 1:1 Langmuir fits estimating Association rate constant ( $k a)(M-1 s-1)$, Dissociation rate constant (kd) (s-1), and Equilibrium dissociation constant (KD) (nM).

Furthermore, Affimer ${ }^{\circledR}$ candidate $620 \_826257$ also displayed good specificity as shown in figure 2, where its positive response to injection of $50 \mathrm{nM}$ SARS-CoV-2 $\mathrm{S} 1$ is compared to the negative response to injections of equally prepared other related human coronavirus S1 proteins (MERS-CoV S1, HCoV-HKU1 S1, SARS-CoV S1 and HCoV-229E S1). 
medRxiv preprint doi: https://doi.org/10.1101/2021.10.28.21265544; this version posted October $29,2021$. The copyright holder for this preprint (which was not certified by peer review) is the author/funder, who has granted medRxiv a license to display the preprint in It is made available under a CC-BY 4.0 International license.

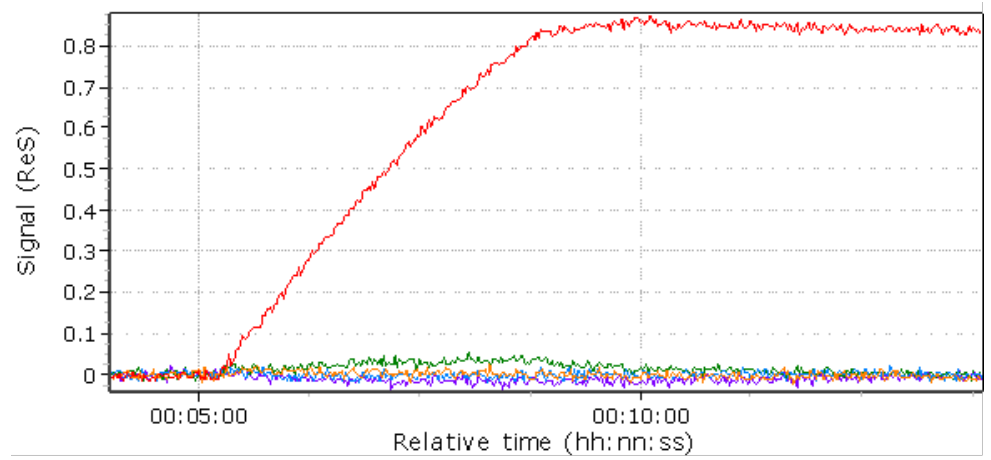

Figure 2. SPRi sensorgrams for Affimer ${ }^{\circledR}$ candidate 620_826257 with injections of 50 nM SARSCoV-2 S1 and other related human coronavirus S1 proteins: MERS-CoV S1, HCoV-HKU1 S1, SARS-CoV S1, HCoV-229E S1.

In order to define the cross-reactivity and interference testing of the aforementioned LFD system (Materials and Methods) with the chosen Affimer $\mathbb{B}$ candidate 620_826257, a specificity profile was completed against recombinant S1 coronavirus targets (Table 1) with cross-reactivity observed for SARS-CoV only. Interference testing was also performed with 3 common nasal sprays (Table 2). Nicorette and Vicks were shown to have no effect on performance of the LFD. Slight interference was observed for Pirinase with reduced intensity of the control and test line. However, no false negatives or positives were observed.

\begin{tabular}{|l|l|l|l|l|}
\hline $\begin{array}{l}\text { Recombinant S1 } \\
\text { Coronavirus tested at } \mathbf{1} \boldsymbol{\mu g} / \mathbf{m} \mathbf{L} \\
\text { in LFD running buffer }\end{array}$ & Supplier & $\begin{array}{l}\text { Catalogue } \\
\text { num ber }\end{array}$ & Lot number & $\begin{array}{l}\text { LFD result } \mathbf{n}=\mathbf{5} \\
\text { (Positive/Negat ive) }\end{array}$ \\
\hline SARS-CoV S1 & Sino Biological & $40150-V 08 B 1$ & LC14AP2102 & Positive \\
\hline MERS-CoV S1 & Sino Biological & $40069-V 08 H$ & LC14AP2601 & Negative \\
\hline HCoV-NL63 & Sino Biological & $40600-V 08 H$ & LC14AP2005 & Negative \\
\hline HCoV-229E & Sino biological & $40601-V 08 H$ & LC14MA0701 & Negative \\
\hline HCoV-OC43 & Sino biological & $40607-V 08 B$ & LC14MA2003 & Negative \\
\hline HKU1 & Sino Biological & 40602-V08H & LC14AP2908 & Negative \\
\hline SARS-CoV-2 & ACRO Biosystems & S1N-C52H4 & $3532 b-204 N F 1-S 1$ & Positive \\
\hline
\end{tabular}

Table 1. LFD specificity profile. Cross-reactivity observed for SARS-CoV only. 
medRxiv preprint doi: https://doi.org/10.1101/2021.10.28.21265544; this version posted October $29,2021$. The copyright holder for this preprint (which was not certified by peer review) is the author/funder, who has granted medRxiv a license to display the preprint in perpetuity.

It is made available under a CC-BY 4.0 International license .

\begin{tabular}{|c|c|c|c|c|}
\hline $\begin{array}{l}\text { Potential Interfering Substances ( } 10 \%) \\
\text { with and without SARS-CoV-2 S1 at } 1 \mu \mathrm{g} / \mathrm{mL} \\
\text { in LFD running buffer }\end{array}$ & Supplier & $\begin{array}{l}\text { Catalogue } \\
\text { number }\end{array}$ & Lot number & $\begin{array}{c}\text { LFD result } \\
\text { (Positive/Negative) }\end{array}$ \\
\hline Pirinase (10\%) & N/A & N/A & AX4G & $\begin{array}{l}\text { Negative }(n=2) \\
\text { Reduced intensity } \\
\text { control line }\end{array}$ \\
\hline Vicks Synex (10\%) & $\mathrm{N} / \mathrm{A}$ & $\mathrm{N} / \mathrm{A}$ & 100017075 & Negative $(n=2)$ \\
\hline Nicorette nasal spray (10\%) & N/A & N/A & BB406 & Negative $(n=2)$ \\
\hline SARS-CoV-2 S1 + Pirinase (10\%) & ACRO Biosystems & $\mathrm{S} 1 \mathrm{~N}-\mathrm{C} 52 \mathrm{H} 4$ & 3532b-204NF1-S1 & $\begin{array}{l}\text { Positive }(n=5) \\
\text { Reduced intensity of } \\
\text { control and test line }\end{array}$ \\
\hline SARS-CoV-2 S1 + Vicks Synex (10\%) & ACRO Biosystems & $\mathrm{S} 1 \mathrm{~N}-\mathrm{C} 52 \mathrm{H} 4$ & 3532b-204NF1-S1 & Positive $(n=5)$ \\
\hline SARS-CoV-2 S1 + Nicorette nasal spray (10\%) & ACRO Biosystems & $\mathrm{S} 1 \mathrm{~N}-\mathrm{C} 52 \mathrm{H} 4$ & 3532b-204NF1-S1 & Positive $(n=5)$ \\
\hline
\end{tabular}

Table 2. LFD interference testing. Cross-reactivity observed for SARS-CoV only.

The final analytical LoD (defined in the former section as the lowest concentration resulting in positive detection of 18 out of 20 replicates $-90 \%$ of all true positive-) was confirmed across a dilution series $\left(10^{4}, 10^{3}, 5 \times 10^{2}, 10^{2}\right.$ and $\left.5 \times 10^{1} \mathrm{pfu} / \mathrm{mL}\right)$. Further testing at $600 \mathrm{pfu} / \mathrm{mL}$ was performed providing positive detection for 19 out of 20 replicates (95\%), setting this final LoD value.

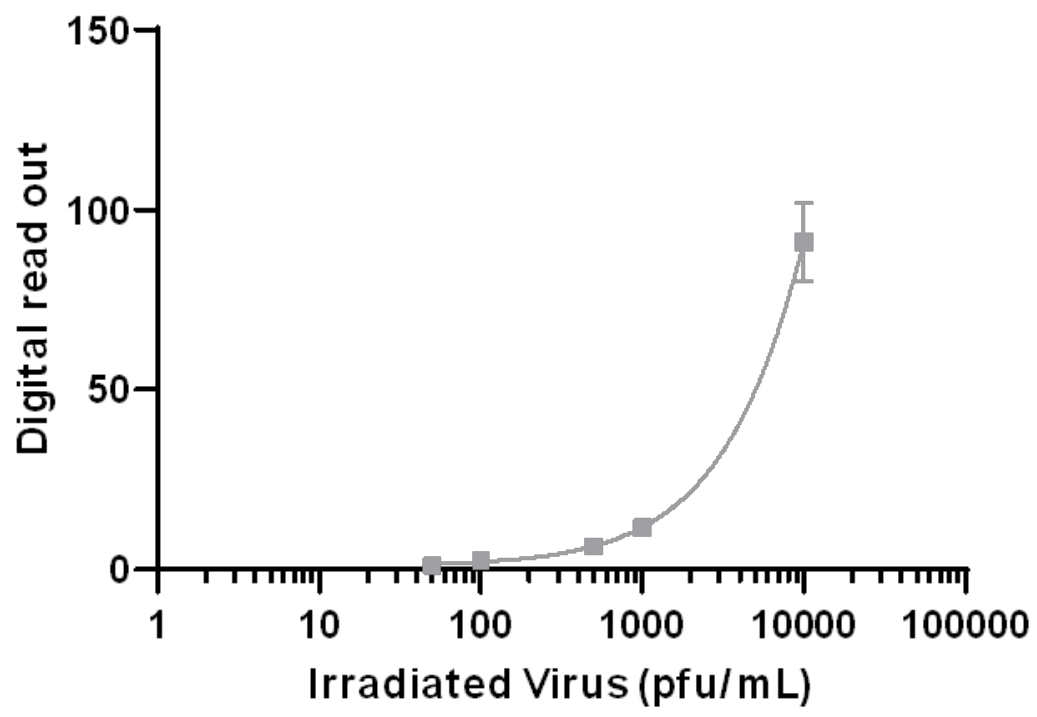

Figure 3. The graph shows digital read outs of the test line intensity against viral titre in $\mathrm{pfu} / \mathrm{mL}$ across a dilution series prepared using pooled (SARS-CoV-2 negative) anterior nasal swab samples, within which the inactivated virus (Englando2 strain lot 19/60) was inoculated to $10^{4}, 10^{3}, 5 \times 10^{2}, 10^{2}$ and $5 \times 10^{1} \mathrm{pfu} / \mathrm{mL}$. 
medRxiv preprint doi: https://doi.org/10.1101/2021.10.28.21265544; this version posted October 29, 2021. The copyright holder for this preprint (which was not certified by peer review) is the author/funder, who has granted medRxiv a license to display the preprint in It is made available under a CC-BY 4.0 International license.

The clinical performance of the AffiDX ${ }^{\circledR}$ SARS-CoV-2 Antigen Rapid test based on the novel SARS-CoV-2 S1 Affimer ${ }^{\circledR}$ technology was evaluated in the study conducted at different investigational sites in Madrid, Spain as it has been detailed in Materials and Methods. The consenting patients of any age, gender, or race/ethnicity who presented at the test site with a former PCR result for COVID19 no older than 4 days were tested. RTqPCR data were the standard for comparison of the results from the nasal swab on the LFD with the AffiDX $®$ SARSCoV-2 Antigen Rapid test based on the novel SARS-CoV-2 S1 Affimer ${ }^{\circledR}$ technology.

150 nasal samples were identified as negative with the AffiDX ${ }^{\circledR}$ SARS-CoV-2 Antigen LFD matching their former 150 negative RTqPCR results. Therefore, there was $100 \%$ correlation for the detection of negative samples as shown in table 3 , with no false positives observed.

\begin{tabular}{|c|c|c|}
\hline Determination & Number of Negative identifications & Specificity \\
\hline PCR & 150 & \\
\hline AffiDX $^{\circledR}$ Antigen - Nasal & 150 & $100 \%$ \\
\hline
\end{tabular}

Table 3. Correlation between RTqPCR and the SARS-CoV-2 Antigen LFD (Avacta ${ }^{\circledR}$ AffiDX ${ }^{\circledR}$ test) for the negative cohort.

98 nasal samples were identified as positive with the AffiDX® SARS-CoV-2 Antigen LFD from the cohort of 100 positive RTqPCR results with a $\mathrm{Ct} \leq 30$, therefore there was $98 \%$ correlation for the detection of positive samples with $\mathrm{Ct}$ values of $\leq 30$. The 98 samples matched within that cohort had the $\mathrm{Ct}$ values of $\leq 28$, therefore there was $100 \%$ correlation for the detection of positive samples with $\mathrm{Ct}$ values of $\leq 28$. The outstanding specimen had the $\mathrm{Ct}$ value $\leq 30$, therefore there was $98 \%$ correlation for the detection of positive samples within the cohort.

\begin{tabular}{|c|c|c|}
\hline Determination & Number of Positive Identifications & Sensitivity \\
\hline PCR & $100(\mathrm{Ct} \leq 30)$ & \\
\hline AffiDx ${ }^{\circledR}$ Antigen - Nasal & 98 & $98 \%$ \\
\hline
\end{tabular}

\begin{tabular}{|c|c|c|}
\hline Determination & Number of Positive Identifications & Sensitivity \\
\hline PCR & $100(\mathrm{Ct} \leq 28)$ & \\
\hline
\end{tabular}


medRxiv preprint doi: https://doi.org/10.1101/2021.10.28.21265544; this version posted October $29,2021$. The copyright holder for this
preprint (which was not certified by peer review) is the author/funder, who has granted medRxiv a license to display the preprint in It is made available under a CC-BY 4.0 International license.

\begin{tabular}{|l|l|l|}
\hline AffiDx ${ }^{\circledR}$ Antigen - Nasal & 100 & $100 \%$ \\
\hline
\end{tabular}

Tables 4.1 and 4.2. Correlation between RTqPCR and the SARS-CoV-2 Antigen LFD (Avacta AffiDX ${ }^{\circledR}$ test) for the positive cohort.

In summary, the clinical results obtained with the AffiDX $®$ SARS-CoV-2 Antigen Lateral Flow Test based on the novel SARS-CoV-2 S1 Affimer $\AA$ technology showed a sensitivity of $98 \%$ and a specificity of $100 \%$ within the cohort tested for a $\mathrm{Ct}$ threshold $\leq 30$. Correlation with the reference positive PCR data for $\mathrm{Ct}$ values of $\leq$ 28 showed 100\%'s of overlap within the cohort tested. Although the exhaustive comparison of performance against other LFD systems is out of the scope of this work, a sub-cohort of 50 specimens with the $C t$ values of $\leq 30$, was tested in parallel using other existing SARS-CoV-2 antigen lateral flow tests. There was $98 \%$ correlation for the detection of positive samples within that cohort for both $\mathrm{Ct}$ values of $\leq 30$ and $\leq 28$, which indicates that the novel Affimer ${ }^{\circledR}$ technology has an edge for detection at lower viral loads (i.e. higher Ct values).

A parallel study under review for publishing will further delve into comparative analysis versus a complete panel of LFDs.

\section{Discussion}

This study is the first to report the journey behind the new AffiDX $®$ SARS-CoV-2 Antigen Lateral Flow Test in terms of in vitro characterisation and clinical performance within a representative cohort. The new AffiDX $®$ SARS-CoV-2 Antigen Lateral Flow Test has shown a strong correlation with the RT-PCR correctly identifying all negative samples and showing no false positives 150/150 (100\%). The system's sensitivity for $\mathrm{Ct} \leq 30$ with $98 / 100$ detected (98\%) is equally interesting as $\mathrm{Ct}$ values $\leq 28$ are considered to be responsible for the vast majority of infectious contacts under an epidemiologic point of view and the system reaches a $100 \%$ sensitivity for $\mathrm{Ct} \leq 28$ with 98/98 detected $(100 \%)^{16}$. 
medRxiv preprint doi: https://doi.org/10.1101/2021.10.28.21265544; this version posted October 29, 2021. The copyright holder for this preprint (which was not certified by peer review) is the author/funder, who has granted medRxiv a license to display the preprint in It is made available under a CC-BY 4.0 International license.

Apart from the strong performance data, this new COVID-19 antigen test is an important addition to available tests because the results can be read in minutes, right off the testing card so that the patient gets the information in almost realtime. Due to its simpler design and real usability in terms of clinical performance within the cohort tested, this new antigen test could mark an important advancement in the global fight against the pandemic.

\section{References}

1. World Health Organization. Antigen-detection in the diagnosis of SARS-CoV-2 infection using rapid immunoassays: interim guidance, 11 September 2020. WHO/2019-nCoV/Antigen_Detection/2020.1. Geneva: World Health Organization; 2020.

2. Mina MJ, Parker R, Larremore DB. Rethinking Covid-19 test sensitivity-a strategy for containment. N Engl J Med. 2020;383(22):e120. pmid:32997903

3. Federal Institute for Drugs and Medical Devices. Antigen-Tests auf SARS-CoV-2. Bonn: Federal Institute for Drugs and Medical Devices; 2021 [cited 2021 Jun 7].

https://www.bfarm.de/DE/Medizinprodukte/Antigentests/_node.html.

4. Krüger LJ, Gaeddert M, Köppel L, Brümmer LE, Gottschalk C, Miranda IB, et al. Evaluation of the accuracy, ease of use and limit of detection of novel, rapid, antigen-detecting point-of-care diagnostics for SARS-CoV-2. medRxiv. 2020 Oct 4.

5 .Denkinger CM, Grenier J, Minion J, Pai M. Promise versus reality: optimism bias in package inserts for tuberculosis diagnostics. J Clin Microbiol. 2012;50(7):2455-61. pmid:22573592

6 .World Health Organization. Advice on the use of point-of-care immunodiagnostic tests for COVID19: scientific brief, 8 April 2020. WHO/2019-nCoV/Sci_Brief/POC_immunodiagnostics/2020.1. Geneva: World Health Organization; 2020.

7. Dinnes J, Deeks JJ, Adriano A, Berhane S, Davenport C, Dittrich S, et al. Rapid, point-of-care antigen and molecular-based tests for diagnosis of SARS-CoV-2 infection. Cochrane Database Syst Rev.

2020;8(8):CD013705. pmid:32845525

8. Woodman R, Yeh JT, Laurenson S, Ko Ferrigno P (October 2005). "Design and validation of a neutral protein scaffold for the presentation of peptide aptamers". Journal of Molecular Biology. 352 (5): 111833. doi:10.1016/j.jmb.2005.08.001. PMID 16139842. 
medRxiv preprint doi: https://doi.org/10.1101/2021.10.28.21265544; this version posted October $29,2021$. The copyright holder for this preprint (which was not certified by peer review) is the author/funder, who has granted medRxiv a license to display the preprint in perpetuity.

It is made available under a CC-BY 4.0 International license .

9. Hoffmann T, Stadler LK, Busby M, Song Q, Buxton AT, Wagner SD, Davis JJ, Ko Ferrigno P (May 2010). "Structure-function studies of an engineered scaffold protein derived from stefin A. I: Development of the SQM variant". Protein Engineering, Design \& Selection. 23 (5): 40313. doi:10.1093/protein/gzq012. PMC 2851446. PMID 20179045.

10. Stadler LK, Hoffmann T, Tomlinson DC, Song Q, Lee T, Busby M, Nyathi Y, Gendra E, Tiede C, Flanagan K, Cockell SJ, Wipat A, Harwood C, Wagner SD, Knowles MA, Davis JJ, Keegan N, Ferrigno PK (September 2011). "Structure-function studies of an engineered scaffold protein derived from Stefin A. II: Development and applications of the SQT variant". Protein Engineering, Design \& Selection. 24 (9): 751-63. doi:10.1093/protein/gzr019. PMID 21616931.

11. Tiede C, Tang AA, Deacon SE, Mandal U, Nettleship JE, Owen RL, George SE, Harrison DJ, Owens RJ, Tomlinson DC, McPherson MJ (May 2014). "Adhiron: a stable and versatile peptide display scaffold for molecular recognition applications". Protein Engineering, Design \& Selection. 27 (5): 14555. doi:10.1093/protein/gzu007. PMC 4000234. PMID 24668773.

11. Sharma R, Deacon SE, Nowak D, George SE, Szymonik MP, Tang AA, Tomlinson DC, Davies AG, McPherson MJ, Wälti C (June 2016). "Label-free electrochemical impedance biosensor to detect human interleukin-8 in serum with sub-pg/ml sensitivity". Biosensors \& Bioelectronics. 80: 607613. doi:10.1016/j.bios.2016.02.028. PMC $\underline{\text { 4785862. PMID } 26897263}$

12. Arrata I, Barnard A, Tomlinson DC, Wilson AJ (March 2017). "Interfacing native and non-native peptides: using Affimers to recognise $\alpha$-helix mimicking foldamers" (PDF). Chemical Communications. 53 (19): 2834-2837. doi:10.1039/c6cc09395g. PMID 28217789.

13. Xie C, Tiede C, Zhang X, Wang C, Li Z, Xu X, McPherson MJ, Tomlinson DC, Xu W (August 2017). "Development of an Affimer-antibody combined immunological diagnosis kit for glypican3". Scientific Reports. 7 (1): 9608. doi:10.1038/s41598-017-10083-w. PMC 5575301. PMID 28852111

14. Tiede C, Bedford R, Heseltine SJ, Smith G, Wijetunga I, Ross R, et al. (June 2017). "Affimer proteins are versatile and renewable affinity

reagents". eLife. 6. doi:10.7554/elife.24903. PMC 5487212. PMID 28654419.

15. Klont $F$, Hadderingh $M$, Horvatovich $P$, Ten Hacken NH, Bischoff R (August 2018). "Affimers as an Alternative to Antibodies in an Affinity LC-MS Assay for Quantification of the Soluble Receptor of Advanced Glycation End-Products (sRAGE) in Human Serum". Journal of Proteome Research. 17 (8): 2892-2899. doi:10.1021/acs.jproteome.8b00414. PMC 6079930. PMID 30005571.

16. Lennard Y W Lee, Stefan Rozmanowski, Matthew Pang, Andre Charlett, Charlotte Anderson, Gareth J Hughes, Matthew Barnard, Leon Peto, Richard Vipond, Alex Sienkiewicz, Susan Hopkins, John Bell, Derrick W Crook, Nick Gent, A Sarah Walker, Tim E A Peto, David W Eyre. "SARS-CoV-2 infectivity by viral load, 
medRxiv preprint doi: https://doi.org/10.1101/2021.10.28.21265544; this version posted October 29, 2021. The copyright holder for this preprint (which was not certified by peer review) is the author/funder, who has granted medRxiv a license to display the preprint in It is made available under a CC-BY 4.0 International license.

$\underline{S}$ gene variants and demographic factors and the utility of lateral flow devices to prevent transmission". Clinical Infection Diseases. 2021 May 11 ;ciab421. doi: 10.1093/cid/ciab421. 